\title{
Using The Apriori Algorithm To Classify The Care Needs Of Patients With Different Types Of Dementia
}

This article was published in the following Dove Press journal:

Patient Preference and Adherence

\author{
Kai-Ming Jhang ${ }^{1} * *$ \\ Ming-Che Chang ${ }^{2, *}$ \\ Tzu-Ying Lo ${ }^{3}$ \\ Che-Wei Lin ${ }^{4}$ \\ Wen-Fu Wang ${ }^{1,5, *}$ \\ Hsin-Hung Wu (D) ${ }^{3,6}$ \\ 'Department of Neurology, Changhua \\ Christian Hospital, Changhua, Taiwan; \\ ${ }^{2}$ Department of Nuclear Medicine, \\ Changhua Christian Hospital, Changhua, \\ Taiwan; ${ }^{3}$ Department of Business \\ Administration, National Changhua \\ University of Education, Changhua, \\ Taiwan; ${ }^{4}$ Medical Divisions of \\ Performance Center, Changhua Christian \\ Hospital, Changhua, Taiwan; \\ ${ }^{5}$ Department of Holistic Wellness, Ming \\ Dao University, Changhua, Taiwan; \\ ${ }^{6}$ Department of M-Commerce and \\ Multimedia Applications, Asia University, \\ Taichung City, Taiwan
}

*These authors contributed equally to this work
Correspondence: Hsin-Hung Wu

No. 2 Shida Road, Changhua City 500,

Taiwan

Tel +88647232105 ext. 7412

Fax +886 4-72II 292

Email hhwu@cc.ncue.edu.tw
Purpose: To elucidate specific combinations of care needs for people living with dementia (PLWD) and their caregivers according to specific subtypes of dementia.

Patients and methods: A cross-sectional study at memory clinics in Changhua Christian Hospital, Taiwan, was conducted. Five hundred and eight people living with dementia and their caregivers joined the dementia collaborative care model. The care team established 15 care needs containing most of quality measures for PLWD and their caregivers. Individualized care plans including different combinations of care needs were addressed through face-to-face assessments. Apriori algorithm was used to find specific combinations of care needs for particular groups of PLWD and their caregivers.

Results: This study identified the basic care needs of PLWD and caregivers including appropriate scheduling of activities, regular outpatient follow-up treatment, introduction and referral of social resources, referral to family support groups and care skills training, and health education for dementia and behavioral and psychological symptoms of dementia. Patients with Alzheimer's dementia required more care to prevent traffic accidents and getting lost, while patients with vascular dementia required more care to prevent falls. The older ( $\geq 75$ years old) PLWD were associated with more needs of fall prevention and care for the mood of the caregiver, especially in the female patients with mild Alzheimer's dementia $(\mathrm{CDR}=1)$.

Conclusion: Bundling the needed care needs might be a more effective means to care for a wide variety of patients with dementia.

Keywords: people living with dementia, behavioral and psychological symptoms of dementia, dementia collaborative care model, care need, Apriori algorithm

\section{Introduction}

Dementia is one of the greatest global challenges for health and social care in the 21 st century. ${ }^{1}$ While prevalence trajectories are unclear in high-income countries, the number of people living with dementia (PLWD) continues to grow globally, especially in low- and middle-income countries. ${ }^{2}$ Some evidence supports that the prevalence of dementia is increasing in East Asia.,

The number of older people in Taiwan has grown rapidly in the past decades, with the percentage of the population over the age of 65 years increasing from $6.8 \%$ in 1992 to $14.1 \%$ in $2018 .^{5}$ The prevalence of all-cause dementia in older Taiwanese in 2014 was $8.04 \%$ according to a nationwide cross-sectional survey, with an estimated 250,000 PLWD in 2018. ${ }^{6}$ PLWD need help with challenging changes in behavior, cognition, and mood, and their caregivers often suffer from the caregiving, depression and health problems. ${ }^{1,7}$ 
To address patients' and caregivers' complex healthcare needs, several collaborative care models have been published in the last decade. ${ }^{8-11}$ These models are characterized by interprofessional teams, multicomponent interventions, and shared decision-making between healthcare professionals and patients as well as their caregivers. ${ }^{12}$ Previous studies have performed comprehensive patient-centered assessments of PLWD and their care partners, including the patient's function, behavior and health status, and their challenges or unmet needs. ${ }^{9,10}$ The goal of a systematic assessment is to identify opportunities to support personhood, reduce safety risks, optimize quality of life, and form team-approached care planning. ${ }^{10}$ Although still controversial, several studies suggest that a collaborative approach improves the quality of care for patens with dementia, increases adherence to dementia guidelines, and decreases behavioral problems. ${ }^{13-15}$

We established a dementia collaborative care model at Changhua Christian Hospital, a medical center in Changhua, Taiwan, in October 2014. The care team includes physicians (including neurologists, psychiatrists, gerontologists, and primary care physicians), psychologists, social workers, dieticians, occupational therapists, pharmacists, and nursing case managers. This team performs patient and care partner interventions when a diagnosis of dementia (including mild cognitive impairment (MCI) and very mild dementia) has been made. More than $95 \%$ of PLWD are community residents at the first intervention. The cognition, function, living status, home environment, behavior and psychological symptoms of the patient, as well as the stress, mood and preference of the caregiver are assessed through both telephone and face-toface interviews. After team-approached assessments, an individualized care plan is formed. The care team addresses 15 different care needs (Table 1) containing most of quality measures and needs for dementia patients and their caregivers. ${ }^{9,10,12,16,17}$ Care needs provide main care targets and guide team members for subsequent follow-up. Each need is addressed when assessments are abnormal (e.g. if the environment is unsafe or there are economic difficulties).

In clinical practice, the collaborative team observed that certain care needs often occur in combination and that some occurred more frequently in people with specific subtypes of dementia. Most previous studies have focused on the prevalence of various care needs of dementia. ${ }^{18-20}$ However, no previous study has attempted to group or classify care needs. Grouping care needs for particular conditions such as the severity or subtype of dementia would allow for more efficient and holistic care. Therefore, the aim of the present study was to elucidate whether specific combinations of care needs can be applied to particular groups of PLWD and their caregivers using the Apriori algorithm, as this algorithm can reveal interesting statistical correlations from a multidimensional viewpoint when each attribute is viewed as a dimension by establishing threshold values of support and confidence. ${ }^{21}$

\section{Materials And Methods}

Patients diagnosed as mild cognitive impairment or dementia at memory clinic from October 2015 to April 2017 in Changhua Christian Hospital were enrolled. The clinical trial was approved by the Institutional Review Board of Changhua Christian Hospital (CCH IRB 160165). Because the design of the present study was a retrospective chart review, informed consent was waived by the Institutional Review Board of Changhua Christian Hospital. All data were recorded in the electronic medical chart with the highest confidentiality and compliance with the Declaration of Helsinki. Six hundred and eight patients who received team-approached assessment were screened, and after excluding those with incomplete data and those with a dementia subtype including fewer than 10 registered patients, the remaining 508 were included for analysis. The demographic information including gender, age, type of dementia, and clinical dementia rating (CDR) is summarized in Table 2. A majority of the patients were women (66\%) with Alzheimer's disease (72\%) aged 75 years and older (82\%) who had mild dementia (51\%). National Institute on Aging-Alzheimer's Association (NIA-AA), ${ }^{22,23}$ International Society for Vascular Behavioral and Cognitive disorders (VASCOG) ${ }^{24}$ and Movement Disorder Society-Task force criteria were used for diagnosis of $\mathrm{AD}$, vascular dementia and Parkinson's disease dementia, respectively. ${ }^{25}$ Patients fit both possible AD by NIA-AA criteria and possible major vascular cognitive disorder by VASCOG criteria were classified as mixed dementia. The 15 care needs listed in Table 1 were then assessed.

The purpose of this study was to identify whether specific combinations of several care needs could be applied to particular groups of PLWD and their caregivers and thereby to provide more efficient and holistic care. That is, we intended to group the care needs for patients with dementia by gender, age, type of dementia, and dementia severity. The Apriori algorithm has been proven to be a very useful approach to discover previously 
Table I Fifteen Care Needs Addressed By Changhua Christian Hospital

\begin{tabular}{|c|c|c|}
\hline Number & Description & Contents \\
\hline I & Adequate nutrition and diet & $\begin{array}{l}\text { This need was selected if the nutritional assessment was abnormal through evaluating a } \\
\text { patient's oral intake ability and recent body weight change. A nursing case manager or } \\
\text { dietician gave individualized nutritional suggestions }\end{array}$ \\
\hline 2 & Maintenance of personal hygiene & $\begin{array}{l}\text { This need was chosen if a patient's activity of daily living was impaired. Care skills } \\
\text { education and in-house reablement program were introduced }\end{array}$ \\
\hline 3 & Appropriate schedule of activities & $\begin{array}{l}\text { This need was targeted if a patient's daily physical activity was low. A nursing case } \\
\text { manager would provide a daily schedule suggestion }\end{array}$ \\
\hline 4 & Adequate sleep and rest & $\begin{array}{l}\text { This need was selected if poor sleep quality was recorded. The study team then provided } \\
\text { sleep hygiene education and discussed the usage of sleep medication }\end{array}$ \\
\hline 5 & Fall prevention & $\begin{array}{l}\text { This need was added if a risk of fall score located within a high-risk group. Physical } \\
\text { training program and assistive devices evaluation were introduced }\end{array}$ \\
\hline 6 & Preventing traffic accidents and getting lost & $\begin{array}{l}\text { This need was chosen if a patient's ambulatory function was preserved with the history } \\
\text { of traffic accident or getting lost due to a cognitive decline. A nursing case manager then } \\
\text { provided the driving ability evaluation and assistive device for prevention of getting lost }\end{array}$ \\
\hline 7 & Preventing misusage of medications & $\begin{array}{l}\text { This need was selected if misusage of medication was detected through asking residual } \\
\text { drugs or from the care partner. Strategies including using drug boxes and decreasing use } \\
\text { frequency were suggested }\end{array}$ \\
\hline 8 & Adjusting home environment safety & $\begin{array}{l}\text { This need was selected if any event of indoor safety concern has been recorded (eg, } \\
\text { overcooked or burning). An experienced nurse or therapist then provided home } \\
\text { environmental evaluation and adjustment }\end{array}$ \\
\hline 9 & Regular outpatient follow-up treatment & $\begin{array}{l}\text { This need was added if a physician suggested a medication treatment. A case manager } \\
\text { would follow the patient every month to maintain adherence }\end{array}$ \\
\hline 10 & $\begin{array}{l}\text { Behavioral and psychological symptoms of } \\
\text { dementia (BPSD) treatment }\end{array}$ & $\begin{array}{l}\text { This need was selected if presence of any BPSD, which was detected through } \\
\text { neuropsychiatric inventory annually. Non-pharmacological treatments were given first } \\
\text { and pharmacological interventions were only reserved for severe patients }\end{array}$ \\
\hline II & Referral to other specialists & $\begin{array}{l}\text { This need was added if any medical problem which needs other subspecialists was } \\
\text { detected during the assessment }\end{array}$ \\
\hline 12 & Introduction and referral of social resources & $\begin{array}{l}\text { This need was selected if PLWD and their caregivers asked social resources such as } \\
\text { disability card, day care facilities, or guardianship }\end{array}$ \\
\hline 13 & $\begin{array}{l}\text { Referral to family support groups and care } \\
\text { skills training }\end{array}$ & $\begin{array}{l}\text { This need was chosen if a high Zarit's caregiver burden score was recorded during the } \\
\text { assessment. Support groups of dementia caregivers were introduced }\end{array}$ \\
\hline 14 & Care for the mood of the caregiver & $\begin{array}{l}\text { This need was selected if a caregiver presented with depressive mood (screen by CES-D). } \\
\text { The caregiver with the severe condition received emotional support and transferred to } \\
\text { psychiatrist }\end{array}$ \\
\hline 15 & Education for dementia and BPSD & $\begin{array}{l}\text { This need was chosen if PLWD and caregivers asked education information about } \\
\text { dementia or BPSD, such as prevention, disease course, and medications. Different } \\
\text { education programs were arranged according to the learning ability }\end{array}$ \\
\hline
\end{tabular}

Abbreviation: CES-D, Center for Epidemiologic Studies-Depression Scale.

unknown interesting relationships in data sets by finding rules and associations between any of the attributes by establishing support, confidence, and lift, which are defined as follows. ${ }^{21,26,27}$ The support for an association rule $\mathrm{A} \Rightarrow \mathrm{B}$ is assessed by calculating the percentage of transactions in the database containing both $\mathrm{A}$ and $\mathrm{B}$ : 
Table 2 Information Of The Patients With Dementia

\begin{tabular}{|l|l|l|l|l|}
\hline \multicolumn{2}{|l|}{ Variables } & Frequency & Percentage & $\begin{array}{l}\text { Data } \\
\text { Type }\end{array}$ \\
\hline Gender & $\begin{array}{l}\text { Male } \\
\text { Female }\end{array}$ & $\begin{array}{l}175 \\
333\end{array}$ & $\begin{array}{l}34 \\
66\end{array}$ & $\begin{array}{l}\text { M } \\
\text { F }\end{array}$ \\
\hline Age & $\begin{array}{l}\text { Less than } 65 \text { years } \\
\text { old }\end{array}$ & 17 & 3 & 0 \\
& $65-69$ years old & 20 & 4 & \\
& $70-74$ years old & 56 & 11 & 1 \\
& $75-79$ years old & 147 & 29 & 2 \\
& $80-84$ years old & 145 & 29 & 4 \\
& 85 years old and & 123 & 24 & 5 \\
& above & & & \\
\hline \multirow{5}{*}{ Type of } & Alzheimer's disease & 363 & 72 & AD \\
dementia & Parkinson's disease & 26 & 5 & PDD \\
& Vascular dementia & 93 & 18 & VaD \\
& Mixed dementia & 26 & 5 & MD \\
\hline CDR & Very mild dementia & 104 & 21 & 0 \\
& Mild dementia & 260 & 51 & 1 \\
& Moderate dementia & 89 & 18 & 2 \\
& Severe dementia & 55 & 11 & 3 \\
\hline
\end{tabular}

Abbreviation: CDR, clinical dementia rating.

$$
=\frac{\text { Support }=\mathrm{P}(\mathrm{A} \cap \mathrm{B})}{\text { number of transactions containing both } \mathrm{A} \text { and } \mathrm{B}}
$$

The confidence of the association rule $\mathrm{A} \Rightarrow \mathrm{B}$ is assessed by evaluating the accuracy of the rule based on the calculation of the percentage of transactions in the database containing A and also containing B simultaneously:

$$
\begin{gathered}
\text { Confidence }=\mathrm{P}(\mathrm{B} \mid \mathrm{A})=\frac{\mathrm{P}(\mathrm{A} \cap \mathrm{B})}{\mathrm{P}(\mathrm{A})} \\
=\frac{\text { number of transactions containing both } \mathrm{A} \text { and } \mathrm{B}}{\text { number of transactions containing } \mathrm{A}}
\end{gathered}
$$

Lift is a simple correlation measuring whether A and B are independent or dependent and correlated events as shown in Equation (3). If a rule has a lift of one, A and B are independent and no rule will be generated containing either event. If a rule has a lift greater than one, A and B are dependent and correlated positively. In practice, analysts tend to prefer rules with either high support or high confidence and usually both. ${ }^{28}$ In fact, strong rules will be found when certain minimum support and confidence conditions have been met.

$$
\operatorname{Lift}(A, B)=\frac{P(A \cap B)}{P(A) P(B)}
$$

The Apriori algorithm in IBM SPSS Modeler 18 was used in this study. The notations of data type defined by numerical values or abbreviations are depicted in Table 2. The input variables for antecedents were gender, age, type of dementia, and CDR. The 15 care needs developed by our hospital were classified as both antecedents and consequents. The notations for each care need were 1 or 0 . If a particular care need was applied to a patient, a value of 1 was assigned. If not, a value of 0 was used. This allowed for the identification of combinations of care needs. Minimum support, minimum confidence, and lift were set to $10 \%$, $90 \%$, and greater than one, respectively. The rules with higher support values indicated that the care need bundles could fulfill the majority of the patients' needs. In contrast, the rules with relatively lower support values indicated that the care need bundles may only be applicable to a small portion of the patients, ie, special needs. The settings of antecedents and consequents in the Apriori algorithm allow the decision-maker to identify what combinations of care needs would be needed according to the specific demographic information of the patients.

\section{Results}

A total of 1759 rules were generated by the Apriori algorithm (Table 3 lists a sample of some of the rules). For instance, Rule 1 indicated that a patient aged 70-74 years required education for dementia and BPSD (Care (15)). Rule 2 showed that preventing the misuse of medications (Care (7)) and Care (15) should be bundled together to meet the needs of the patient. Rule 3 depicted that a patient with Alzheimer's disease needed Care (7) and the introduction and referral of social resources (Care (12)). In Rule 4, a patient with moderate dementia needed both fall prevention (Care (5)) and also education for dementia and BPSD (Care (15)). Rule 5 suggested that Care (7), Care (12), and Care (9) (regular outpatient follow-up treatment) should be combined with Care (15). Of note, confidence in Rule 5 was $100 \%$, showing that these four rules could definitely be bundled for patients with dementia. Moreover, in Rule 6, the combination of Care (13), Care (12), Care (3), Care (15), and Care (9) could meet the needs of $53.54 \%$ of the PLWD.

In order to categorize the rules effectively, the 1759 rules were divided into four categories in terms of different support values, ie, $40 \%$ and above, $30 \%$ but less than $40 \%$, $20 \%$ but less than $30 \%$, and $10 \%$ but less than $20 \%$. Rules that had both high support and confidence values could be viewed as the basic requirements for PLWD. That is, the identified care needs could be bundled as a portfolio for PLWD at the first intervention. In contrast, rules with 
Table 3 Information Of The Patients With Dementia

\begin{tabular}{|c|c|c|c|c|c|c|}
\hline Rule No. & Antecedent & Consequent & $\begin{array}{l}\text { No. Of Cases } \\
\text { In The Database }\end{array}$ & Support (\%) & Confidence (\%) & Lift \\
\hline I & Age $=2$ & Care $(15)=1$ & 56 & 11.02 & 98.21 & 1.04 \\
\hline 2 & Care $(7)=1$ & Care $(15)=1$ & 66 & 12.99 & 98.49 & 1.04 \\
\hline 3 & $\begin{array}{l}\text { Care }(7)=1 \\
\text { Type = AD }\end{array}$ & Care $(12)=1$ & 51 & 10.04 & 90.20 & 1.12 \\
\hline 4 & $\begin{array}{l}C D R=2 \\
\text { Care }(5)=1\end{array}$ & Care $(15)=1$ & 51 & 10.04 & 96.08 & 1.01 \\
\hline 5 & $\begin{array}{l}\text { Care }(7)=1 \\
\text { Care }(12)=1 \\
\text { Care }(9)=1\end{array}$ & Care $(15)=1$ & 51 & 10.04 & 100.00 & 1.05 \\
\hline 6 & $\begin{array}{l}\text { Care }(13)=1 \\
\text { Care }(12)=1 \\
\text { Care }(3)=1 \\
\text { Care }(15)=1\end{array}$ & Care $(9)=1$ & 272 & 53.54 & 91.54 & 1.04 \\
\hline
\end{tabular}

lower support but high confidence values could be considered as special needs for a very small group of PLWD.

With support of $40 \%$ and above, five basic care needs were identified for the majority of the patients, including appropriate scheduling of activities (Care (3)), regular outpatient follow-up treatment (Care (9)), introduction and referral of social resources (Care (12)), referral to family support groups and care skills training (Care (13)), and education for dementia and BPSD (Care (15)). With support of $30 \%$ but less than $40 \%$, in addition to the five basic care needs for the majority of the patients, four additional care needs were identified, including adequate sleep and rest (Care (4)), preventing traffic accidents and getting lost (Care (6)), adjusting home environment safety (Care (8)), and care for the mood of the caregiver (Care (14)).

When the support was $20 \%$ but less than $30 \%$, three generalized rules were identified as shown in Table 4. The first generalized rule indicated that a patient with Alzheimer's disease who required the five basic care needs should further receive interventions to prevent traffic accidents and getting lost (Care (6)). The second generalized rule indicated that a patient with Alzheimer's disease is required to focus on fall prevention (Care (5)) in addition to the five basic care needs. Moreover, the third generalized rule depicted that a patient with mild dementia needs to further focus on fall prevention (Care (5)). That is, the caregiver was required to pay extra attention to prevent traffic accidents and getting lost as well as fall prevention for a patient with Alzheimer's disease.
With support of $10 \%$ but less than $20 \%$, nine generalized rules were identified as shown in Table 5. The first generalized rule indicated that a patient with vascular dementia needed additional interventions to prevent falls (Care (5)) in addition to the five basic care needs. In the second generalized rule, a patient with moderate Alzheimer's disease was required to the five basic care needs. In the third generalized rule, with the confidence value of $100 \%$, a female patient aged 75-79 years with Alzheimer's disease was required to receive the five basic care needs. The fourth generalized rule said that a patient with moderate dementia needed additional interventions to prevent falls (Care (5)) in addition to the five basic needs. In contrast, a female patient with moderate dementia was required to concentrate on Care (9) and Care (15) of the five basic care needs as shown in the fifth generalized rule. In the sixth generalized rule, a female patient aged 75-79 years is required to have five basic care needs with a confidence value of $100 \%$. In contrast to the sixth generalized rule, the seventh rule showed that patients aged 75-79 years required the five basic care needs with a confidence value of $100 \%$, and the caregiver's stress and mood should also be monitored (Care (14)). That is, the caregivers may suffer from the caregiving, depression, and health problems when caring for patients aged 75-79 years. The eighth generalized rule indicated that the patients with mild dementia aged 80-84 years required additional interventions for fall prevention (Care (5)) in addition to the five basic care needs with a 
Table 4 Three Generalized Rules With Support Of 20\% But Less Than 30\%

\begin{tabular}{|c|c|c|c|c|c|c|}
\hline Rule & Antecedent & Consequent & No. Of Cases In The Database & Support (\%) & Confidence (\%) & Lift \\
\hline \multirow[t]{8}{*}{ I } & $\begin{array}{l}\text { Care }(6)=1 \\
\text { Type = AD } \\
\text { Care }(9)=1\end{array}$ & Care $(15)=1$ & 108 & 21.26 & 98.15 & 1.03 \\
\hline & $\begin{array}{l}\text { Care }(6)=1 \\
\text { Type = AD }\end{array}$ & Care $(15)=1$ & 121 & 23.82 & 96.69 & 1.02 \\
\hline & $\begin{array}{l}\text { Care }(6)=1 \\
\text { Type }=\text { AD } \\
\text { Care }(12)=1\end{array}$ & Care $(15)=1$ & 113 & 22.24 & 96.46 & 1.02 \\
\hline & $\begin{array}{l}\text { Care }(6)=1 \\
\text { Type = AD }\end{array}$ & Care $(12)=1$ & 121 & 23.82 & 93.39 & 1.16 \\
\hline & $\begin{array}{l}\text { Care }(6)=1 \\
\text { Type }=\text { AD } \\
\text { Care }(15)=1\end{array}$ & Care $(12)=1$ & 117 & 23.03 & 93.16 & 1.15 \\
\hline & $\begin{array}{l}\text { Care }(6)=1 \\
\text { Type }=\text { AD } \\
\text { Care }(9)=1\end{array}$ & Care $(12)=1$ & 108 & 21.26 & 92.59 & 1.15 \\
\hline & $\begin{array}{l}\text { Care }(6)=1 \\
\text { Type }=\text { AD } \\
\text { Care }(9)=1 \\
\text { Care }(15)=1\end{array}$ & Care $(12)=1$ & 106 & 20.87 & 92.45 & 1.15 \\
\hline & $\begin{array}{l}\text { Care }(6)=1 \\
\text { Type = AD } \\
\text { Care }(15)=1\end{array}$ & Care $(9)=1$ & 117 & 23.03 & 90.60 & 1.03 \\
\hline \multirow[t]{4}{*}{2} & $\begin{array}{l}\text { Care }(5)=1 \\
\text { Type }=\text { AD } \\
\text { Care }(3)=1\end{array}$ & Care $(15)=1$ & 114 & 22.44 & 96.49 & 1.02 \\
\hline & $\begin{array}{l}\text { Care }(5)=1 \\
\text { Type = AD } \\
\text { Care }(9)=1\end{array}$ & Care $(15)=1$ & 113 & 22.24 & 96.46 & 1.02 \\
\hline & $\begin{array}{l}\text { Care }(5)=1 \\
\text { Type = AD }\end{array}$ & Care $(15)=1$ & 130 & 25.59 & 96.15 & 1.01 \\
\hline & $\begin{array}{l}\text { Care }(5)=1 \\
\text { Type }=\text { AD } \\
\text { Care }(12)=1\end{array}$ & Care $(9)=1$ & 104 & 20.47 & 90.39 & 1.03 \\
\hline \multirow[t]{4}{*}{3} & $\begin{array}{l}\text { Care }(5)=1 \\
C D R=1\end{array}$ & Care $(15)=1$ & 111 & 21.85 & 96.40 & 1.02 \\
\hline & $\begin{array}{l}\text { Care }(5)=1 \\
\text { CDR }=1 \\
\text { Care }(9)=1\end{array}$ & Care $(15)=1$ & 102 & 20.08 & 96.08 & 1.01 \\
\hline & $\begin{array}{l}\text { Care }(5)=1 \\
C D R=1\end{array}$ & Care $(9)=1$ & 111 & 21.85 & 91.89 & 1.04 \\
\hline & $\begin{array}{l}\text { Care }(5)=1 \\
\text { CDR }=1 \\
\text { Care }(15)=1\end{array}$ & Care $(9)=1$ & 107 & 21.06 & 91.59 & 1.04 \\
\hline
\end{tabular}


Table 5 Nine Generalized Rules With The Support Of 10\% But Less Than 20\%

\begin{tabular}{|c|c|c|c|c|c|c|}
\hline Rule & Antecedent & Consequent & No. Of Cases In The Database & Support (\%) & Confidence (\%) & Lift \\
\hline \multirow[t]{12}{*}{1} & $\begin{array}{l}\text { Type }=\mathrm{VaD} \\
\text { Care }(12)=1\end{array}$ & Care $(15)=1$ & 70 & 13.780 & 95.71 & 1.01 \\
\hline & $\begin{array}{l}\text { Type }=\text { VaD } \\
\text { Care }(12)=1 \\
\text { Care }(3)=1\end{array}$ & Care $(15)=1$ & 52 & 10.24 & 98.08 & 1.03 \\
\hline & $\begin{array}{l}\text { Type }=\text { VaD } \\
\text { Care }(12)=1 \\
\text { Care }(9)=1\end{array}$ & Care $(15)=1$ & 62 & 12.21 & 96.77 & 1.02 \\
\hline & $\begin{array}{l}\text { Type }=\text { VaD } \\
\text { Care }(13)=1 \\
\text { Care }(12)=1\end{array}$ & Care $(15)=1$ & 60 & 11.81 & 95.00 & 1.01 \\
\hline & $\begin{array}{l}\text { Type }=\text { VaD } \\
\text { Care }(13)=1 \\
\text { Care }(12)=1\end{array}$ & Care $(9)=1$ & 60 & 11.81 & 91.67 & 1.04 \\
\hline & $\begin{array}{l}\text { Type }=\text { VaD } \\
\text { Care }(13)=1 \\
\text { Care }(12)=1 \\
\text { Care }(15)=1\end{array}$ & Care $(9)=1$ & 57 & 11.22 & 92.98 & 1.05 \\
\hline & $\begin{array}{l}\text { Type }=\text { VaD } \\
\text { Care }(13)=1 \\
\text { Care }(12)=1 \\
\text { Care }(9)=1\end{array}$ & Care $(15)=1$ & 55 & 10.83 & 96.36 & 1.02 \\
\hline & $\begin{array}{l}\text { Type }=\text { VaD } \\
\text { Care }(13)=1 \\
\text { Care }(15)=1\end{array}$ & Care $(9)=1$ & 64 & 12.60 & 90.63 & 1.03 \\
\hline & $\begin{array}{l}\text { Type }=\text { VaD } \\
\text { Care }(13)=1 \\
\text { Care }(9)=1 \\
\text { Care }(15)=1\end{array}$ & Care $(12)=1$ & 58 & 11.42 & 91.38 & 1.13 \\
\hline & $\begin{array}{l}\text { Type }=\mathrm{VaD} \\
\text { Care (3) }=1\end{array}$ & Care $(15)=1$ & 65 & 12.80 & 96.92 & 1.02 \\
\hline & $\begin{array}{l}\text { Type }=\text { VaD } \\
\text { Care }(3)=1 \\
\text { Care (9) }=1\end{array}$ & Care $(15)=1$ & 58 & 11.42 & 96.55 & 1.02 \\
\hline & $\begin{array}{l}\text { Type }=\text { VaD } \\
\text { Care (5) = I }\end{array}$ & Care $(9)=1$ & 51 & 10.04 & 92.16 & 1.05 \\
\hline \multirow[t]{4}{*}{2} & $\begin{array}{l}C D R=2 \\
\text { Type }=A D \\
\text { Care }(9)=1\end{array}$ & Care $(15)=1$ & 57 & 11.22 & 96.49 & 1.02 \\
\hline & $\begin{array}{l}C D R=2 \\
\text { Type }=A D \\
\text { Care }(3)=1\end{array}$ & Care $(15)=1$ & 57 & 11.22 & 98.25 & 1.04 \\
\hline & $\begin{array}{l}C D R=2 \\
\text { Type }=A D \\
\text { Care }(12)=1\end{array}$ & Care $(15)=1$ & 55 & 10.83 & 96.36 & 1.02 \\
\hline & $\begin{array}{l}C D R=2 \\
\text { Type }=A D\end{array}$ & Care $(15)=1$ & 66 & 12.99 & 96.97 & 1.02 \\
\hline
\end{tabular}

(Continued) 
Table 5 (Continued).

\begin{tabular}{|c|c|c|c|c|c|c|}
\hline Rule & Antecedent & Consequent & No. Of Cases In The Database & Support (\%) & Confidence (\%) & Lift \\
\hline \multirow[t]{5}{*}{3} & $\begin{array}{l}\text { Age }=3 \\
\text { Gender }=\text { F } \\
\text { Type }=\text { AD } \\
\text { Care }(12)=1 \\
\text { Care }(3)=1\end{array}$ & Care $(15)=1$ & 60 & 11.81 & 100 & 1.05 \\
\hline & $\begin{array}{l}\text { Age }=3 \\
\text { Gender }=F \\
\text { Type }=\text { AD } \\
\text { Care }(12)=1 \\
\text { Care }(9)=1\end{array}$ & Care $(15)=1$ & 70 & 13.78 & 100 & 1.05 \\
\hline & $\begin{array}{l}\text { Age }=3 \\
\text { Gender }=\mathrm{F} \\
\text { Type }=\text { AD } \\
\text { Care }(13)=1 \\
\text { Care }(12)=1\end{array}$ & Care $(15)=1$ & 64 & 12.60 & 100 & 1.05 \\
\hline & $\begin{array}{l}\text { Age }=3 \\
\text { Gender }=F \\
\text { Type }=A D \\
\text { Care }(13)=1 \\
\text { Care }(3)=1\end{array}$ & Care $(15)=1$ & 55 & 10.83 & 100 & 1.05 \\
\hline & $\begin{array}{l}\text { Age }=3 \\
\text { Gender }=F \\
\text { Type }=\text { AD } \\
\text { Care }(13)=1 \\
\text { Care }(9)=1\end{array}$ & Care $(15)=1$ & 64 & 12.60 & 100 & 1.05 \\
\hline \multirow[t]{2}{*}{4} & $\begin{array}{l}C D R=2 \\
\text { Care }(5)=1\end{array}$ & Care $(15)=1$ & 51 & 10.04 & 96.08 & 1.01 \\
\hline & $\begin{array}{l}C D R=2 \\
\text { Care (5) }=1\end{array}$ & Care $(9)=1$ & 51 & 10.04 & 90.20 & 1.02 \\
\hline \multirow[t]{3}{*}{5} & $\begin{array}{l}C D R=2 \\
\text { Gender }=\mathrm{F} \\
\text { Care }(15)=1\end{array}$ & Care $(9)=1$ & 53 & 10.43 & 90.57 & 1.03 \\
\hline & $\begin{array}{l}C D R=2 \\
\text { Gender }=F\end{array}$ & Care $(15)=1$ & 54 & 10.63 & 98.15 & 1.03 \\
\hline & $\begin{array}{l}C D R=2 \\
\text { Gender }=F\end{array}$ & Care $(9)=1$ & 54 & 10.63 & 90.74 & 1.03 \\
\hline \multirow[t]{2}{*}{6} & $\begin{array}{l}\text { Age }=3 \\
\text { Gender }=\mathrm{F} \\
\text { Care }(12)=1 \\
\text { Care }(3)=1 \\
\text { Care }(9)=1\end{array}$ & Care $(15)=1$ & 64 & 12.60 & 100 & 1.05 \\
\hline & $\begin{array}{l}\text { Age }=3 \\
\text { Gender }=\mathrm{F} \\
\text { Care }(13)=1 \\
\text { Care }(3)=1 \\
\text { Care }(9)=1\end{array}$ & Care $(15)=1$ & 61 & 12.01 & 100 & 1.05 \\
\hline
\end{tabular}

(Continued) 
Table 5 (Continued).

\begin{tabular}{|c|c|c|c|c|c|c|}
\hline Rule & Antecedent & Consequent & No. Of Cases In The Database & Support (\%) & Confidence (\%) & Lift \\
\hline \multirow[t]{6}{*}{7} & $\begin{array}{l}\text { Age }=3 \\
\text { Care }(13)=1 \\
\text { Care }(12)=1 \\
\text { Care }(3)=1 \\
\text { Care }(9)=1\end{array}$ & Care $(15)=1$ & 78 & 15.35 & 100 & 1.05 \\
\hline & $\begin{array}{l}\text { Age }=3 \\
\text { Care }(13)=1 \\
\text { Care }(3)=1 \\
\text { Care }(9)=1\end{array}$ & Care $(15)=1$ & 85 & 16.73 & 100 & 1.05 \\
\hline & $\begin{array}{l}\text { Age }=3 \\
\text { Care }(14)=1 \\
\text { Care }(13)=1 \\
\text { Care }(3)=1\end{array}$ & Care $(15)=1$ & 51 & 10.04 & 100 & 1.05 \\
\hline & $\begin{array}{l}\text { Age }=3 \\
\text { Care }(14)=1 \\
\text { Care }(3)=1\end{array}$ & Care $(15)=1$ & 62 & 12.21 & 100 & 1.05 \\
\hline & $\begin{array}{l}\text { Age }=3 \\
\text { Care }(14)=1 \\
\text { Care }(3)=1 \\
\text { Care }(9)=1\end{array}$ & Care $(15)=1$ & 54 & 10.63 & 100 & 1.05 \\
\hline & $\begin{array}{l}\text { Age }=3 \\
\text { Care }(14)=1 \\
\text { Type = AD } \\
\text { Care }(9)=1\end{array}$ & Care $(15)=1$ & 53 & 10.43 & 100 & 1.05 \\
\hline \multirow[t]{6}{*}{8} & $\begin{array}{l}\text { Age }=4 \\
C D R=1 \\
\text { Care }(13)=1\end{array}$ & Care $(15)=1$ & 63 & 12.40 & 100 & 1.05 \\
\hline & $\begin{array}{l}\text { Age }=4 \\
\text { CDR }=1 \\
\text { Care }(13)=1 \\
\text { Care }(12)=1\end{array}$ & Care $(15)=1$ & 55 & 10.83 & 100 & 1.05 \\
\hline & $\begin{array}{l}\text { Age }=4 \\
\text { CDR }=1 \\
\text { Care }(13)=1 \\
\text { Care }(12)=1 \\
\text { Care }(3)=1\end{array}$ & Care $(15)=1$ & 51 & 10.04 & 100 & 1.05 \\
\hline & $\begin{array}{l}\text { Age }=4 \\
\text { CDR }=1 \\
\text { Care }(13)=1 \\
\text { Care }(3)=1\end{array}$ & Care $(15)=1$ & 57 & 11.22 & 100 & 1.05 \\
\hline & $\begin{array}{l}\text { Age }=4 \\
\text { CDR }=1 \\
\text { Care }(13)=1 \\
\text { Care }(3)=1 \\
\text { Care }(9)=1\end{array}$ & Care $(15)=1$ & 53 & 10.43 & 100 & 1.05 \\
\hline & $\begin{array}{l}\text { Age }=4 \\
\text { CDR }=1 \\
\text { Care }(13)=1 \\
\text { Care }(9)=1\end{array}$ & Care $(15)=1$ & 58 & 11.42 & 100 & 1.05 \\
\hline
\end{tabular}

(Continued) 
Table 5 (Continued).

\begin{tabular}{|c|c|c|c|c|c|c|}
\hline Rule & Antecedent & Consequent & No. Of Cases In The Database & Support (\%) & Confidence (\%) & Lift \\
\hline & $\begin{array}{l}\text { Age }=4 \\
\text { Care }(5)=1 \\
\text { Care }(3)=1\end{array}$ & Care $(15)=1$ & 57 & 11.22 & 100 & 1.05 \\
\hline \multirow[t]{10}{*}{9} & $\begin{array}{l}\text { Care }(8)=1 \\
\text { Care }(12)=1 \\
\text { Care }(3)=1 \\
\text { Care }(9)=1\end{array}$ & Care $(15)=1$ & 97 & 19.09 & 100 & 1.05 \\
\hline & $\begin{array}{l}\text { Care }(8)=1 \\
\text { Care }(13)=1 \\
\text { Care }(12)=1 \\
\text { Care }(3)=1\end{array}$ & Care $(15)=1$ & 90 & 17.72 & 100 & 1.05 \\
\hline & $\begin{array}{l}\text { Care }(8)=1 \\
\text { Care }(13)=1 \\
\text { Care }(12)=1 \\
\text { Care }(3)=1 \\
\text { Care }(9)=1\end{array}$ & Care $(15)=1$ & 80 & 15.75 & 100 & 1.05 \\
\hline & $\begin{array}{l}\text { Care }(8)=1 \\
\text { Care }(14)=1 \\
\text { Care }(12)=1 \\
\text { Care }(3)=1\end{array}$ & Care $(15)=1$ & 56 & 11.02 & 100 & 1.05 \\
\hline & $\begin{array}{l}\text { Care }(8)=1 \\
\text { Care }(14)=1 \\
\text { Care }(3)=1 \\
\text { Care }(9)=1\end{array}$ & Care $(15)=1$ & 59 & 11.61 & 100 & 1.05 \\
\hline & $\begin{array}{l}\text { Care }(6)=1 \\
\text { Care }(8)=1 \\
\text { Care }(12)=1 \\
\text { Care }(3)=1\end{array}$ & Care $(15)=1$ & 52 & 10.24 & 100 & 1.05 \\
\hline & $\begin{array}{l}\text { Care }(6)=1 \\
\text { Care }(8)=1 \\
\text { Care }(12)=1 \\
\text { Care }(3)=1 \\
\text { Care }(9)=1\end{array}$ & Care $(15)=1$ & 51 & 10.04 & 100 & 1.05 \\
\hline & $\begin{array}{l}\text { Care }(6)=1 \\
\text { Care }(8)=1 \\
\text { Care }(12)=1 \\
\text { Care }(9)=1\end{array}$ & Care $(15)=1$ & 59 & 11.61 & 100 & 1.05 \\
\hline & $\begin{array}{l}\text { Care }(6)=1 \\
\text { Care }(8)=1 \\
\text { Care }(13)=1 \\
\text { Care }(12)=1\end{array}$ & Care $(15)=1$ & 51 & 10.04 & 100 & 1.05 \\
\hline & $\begin{array}{l}\text { Care }(6)=1 \\
\text { Care }(8)=1 \\
\text { Care }(3)=1 \\
\text { Care }(9)=1\end{array}$ & Care $(15)=1$ & 57 & 11.22 & 100 & 1.05 \\
\hline
\end{tabular}

confidence value of $100 \%$. Given that the third, sixth, seventh, and eighth generalized rules had $100 \%$ confidence, the five basic care needs were required for the
PLWD aged 75 years and older. Moreover, fall prevention and caring for the mood of the caregiver were also essential care needs. 
The ninth generalized rule further considered preventing traffic accidents and getting lost (Care (6)) and adjusting home environment safety (Care (8)) or adjusting home environment safety and care for the mood of the caregiver (Care (14)) in addition to the five basic care needs. In practice, Care (6), Care (8), and Care (14) could be bundled together. Although the generalized rule had a relatively lower support value, the consequent care need was indicated when the antecedent care needs had a confidence value of $100 \%$. Bundling the care needs may be a more effective means to care for patients with dementia.

\section{Discussion}

To the best of our knowledge, this is the first study to extensively evaluate the care needs of PLWD and their caregivers and to differentiate them according to the severity and subtype of dementia. The most common combinations of care needs were appropriate scheduling of activities, regular outpatient follow-up treatment, introduction and referral of social resources, referral to family support groups and care skills training, and education for dementia and BPSD. These needs occurred frequently and simultaneously with one another. Black et $\mathrm{al}^{18}$ reported that the most common unmet needs of community-residing PLWD were safety, followed by meaningful activities, and medical care. For the caregivers, more than $85 \%$ had unmet needs of resource referral and education. Eichler et $\mathrm{al}^{19}$ reported that the most frequent unmet needs of patients with primary care dementia were nursing treatment and care, social counseling and legal support, and pharmaceutical treatment and care. The results of the present study are consistent with those of the previous studies and further strengthened the fundamental role of these needs. The five basic needs can be viewed as basic care needs for PLWD and their care partners, and a collaborative team should consider these needs as first priority care.

Other less frequent combinations were preventing traffic accidents and getting lost, adjusting home environment safety, and caring for the mood of the caregiver. When one of the care needs was selected, the others were usually also present. Our previous study showed that caregivers have the highest burden when taking care of patients who do not need help with daily activities (that is, they can walk around and do housework). ${ }^{27}$ PLWD have a high risk of getting lost and having household emergencies if they still have the ability to perform daily activities, which then increases the caregiver's burden. This suggests that if one of the needs is unmet, case managers should pay more attention to the other two care needs.

The present study also found that the care needs were different for specific subtypes and severity of dementia. Except for the five basic care needs, patients with Alzheimer's dementia had needs for preventing traffic accidents and getting lost and fall prevention, while patients with vascular dementia needed more attention for fall prevention. The older ( $\geq 75$ years old) PLWD were associated with more needs of fall prevention and care for the mood of the caregiver, especially in the female patients with mild Alzheimer's dementia $(C D R=1)$. Whereas, patients with moderate dementia $(\mathrm{CDR}=2)$ were associated with greater needs of fall prevention, particularly in female patients with Alzheimer's dementia. Previous studies have discussed the different care needs of patients with mild cognitive impairment or dementia and for those with young onset dementia. ${ }^{20,29}$ However, only a few studies have focused on care needs for specific types of dementia, and studies on the care needs specific for patients with vascular cognitive impairment are lacking. ${ }^{30,31}$ Currently, no studies have compared the care needs for patients with different etiologies of dementia. The present study highlights the shortage of related research and provides a future direction for research

The strengths of this study include that it provides a more comprehensive viewpoint by combining various care needs using a scientific method. Most previous studies have only shown the percentage of each unmet need for PLWD and their caregivers. ${ }^{18-20}$ Through the identification of the most common care needs, collaborative team members can understand the care focus more efficiently, especially for elementary dementia case managers Another strength is the Apriori algorithm combining various variables to identify the care needs for particular conditions. Unlike previous studies such as Black et al ${ }^{18}$ and Eichler et al $^{19}$ which only evaluated one or more variables causing a higher degree of unmet needs, our results provide a more clear scenario. For example, the appropriate care needs for elderly female PLWD with mild-stage Alzheimer's disease were appropriate scheduling of activities, regular outpatient follow-up treatment, education for dementia and BPSD, and fall prevention. Care needs for their caregivers were introduction and referral of social resources, referral to family support groups and care skills training, and care for their mood.

This study did not include some care needs of dementia that have been reported in past reviews, including early dementia evaluation and diagnosis and advanced care 
planning. ${ }^{9,17}$ Because of the convenience and accessibility to medical care in Taiwan, PLWD and their care partners have easy access to subspecialists, especially in urban areas. People with suspected dementia usually receive a final etiological diagnosis within 1 month after complete evaluations. Therefore, early dementia evaluation and diagnosis were not considered as care needs for the PLWD and caregivers in this study. Advanced care planning is an important care need in patients with incurable chronic illnesses. The Patient Autonomy Act was passed in December 2015 in Taiwan and has been enforced since January 2019, which safeguards the medical autonomy and end-of-life rights of Taiwanese residents. In our site, the advanced care planning has been implemented for every PLWD who can name a surrogate decision-maker since 2016. Because our collaborative care model was implemented in October 2014, the advanced care planning was not selected as one of the care needs for dementia.

The quality measures and needs for patients with MCI were still unclear. However, American Academy of Neurology practice guideline ${ }^{32}$ for MCI highlighted the importance of the assessment and treatment of BPSD, financial and driving safety evaluation, and treatment and prognosis education in MCI patients. Therefore, the present study included MCI patients with a suspected etiology according to the best opinion at diagnosis and provided collaborative care. Only 5\% of the subjects had Lewy body disease, and none had frontotemporal dementia in the present study. Further studies are needed to investigate the care needs of people with those subtypes of dementia. The present study did not include caregiver's characteristics, which may also have influenced the care needs. ${ }^{33}$

\section{Limitation}

The Apriori algorithm, which is one of the most commonly seen association rules, has been widely used to discover previously unknown interesting relationships in data sets by finding rules and associations between any of the attributes by establishing support, confidence, and lift. However, there are some limitations when the Apriori algorithm is used. First, there is no universal approach to set up support and confidence values in order to generate association rules. In general, a higher confidence value, say $90 \%$ or above, is recommended when a conditional probability is applied to study the associations of attributes. In contrast to confidence, setting a higher support value would reduce the number of rules that might result in missing some essential rules with low frequencies, ie, lower support values. On the other hand, setting a lower support value could result in a large number of rules that might hinder the management to summarize rules because rules should be examined manually to determine whether or not they are meaningful. Therefore, there is a trade-off between higher or lower support values. Second, the Apriori algorithm could be viewed as a screening approach to identify associations among a wide variety of attributes by setting up support and confidence values. Other approaches such as decision trees can be applied to reduce ambiguity in a decisionmaking process by assigning specific values to the problem, decisions, and outcomes of each decision.

\section{Conclusion}

Most previous studies have focused on the percentage of each unmet need for patients with dementia and their caregivers, however no studies have classified care needs. ${ }^{18-20}$ Grouping care needs according to the severity or subtype of dementia may allow for more efficient and holistic care. This study used the Apriori algorithm to elucidate whether care needs can be bundled to meet the needs of particular groups of PLWD and their caregivers and identified the basic care needs including appropriate scheduling of activities, regular outpatient follow-up treatment, introduction and referral of social resources, referral to family support groups and care skills training, and education for dementia and BPSD. In addition, patients with Alzheimer's dementia required more care to prevent traffic accidents and getting lost as well as fall prevention, while patients with vascular dementia required more care to prevent falls. Bundling care needs may be a more effective means to care for a wide variety of patients with dementia.

\section{Author Contributions}

All authors contributed to data analysis, drafting or revising the article, gave final approval of the version to be published, and agree to be accountable for all aspects of the work.

\section{Disclosure}

The authors report no conflicts of interest in this work.

\section{References}

1. Livingston G, Sommerlad A, Orgeta V, et al. Dementia prevention, intervention, and care. Lancet. 2017;390(10113):2673-2734. doi:10.1016/S0140-6736(17)31363-6

2. Prince M, Bryce R, Albanese E, Wimo A, Ribeiro W, Ferri CP. The global prevalence of dementia: a systematic review and metaanalysis. Alzheimers Dement. 2013;9(1):63-75e2. doi:10.1016/j.jalz.2012.11.007 
3. Prince M, Ali G-C, Guerchet M, Prina AM, Albanese E, Wu Y-T. Recent global trends in the prevalence and incidence of dementia, and survival with dementia. Alzheimer's Res Ther. 2016;8(1):23 doi:10.1186/s13195-016-0188-8

4. Wu YT, Lee HY, Norton S, et al. Prevalence studies of dementia in mainland China, Hong Kong and Taiwan: a systematic review and meta-analysis. PLoS One. 2013;8(6):e66252. doi:10.1371/journal. pone. 0066252

5. Statistical Yearbook of Interior 2018. Available from: https:/www.moi. gov.tw/stat/news_detail.aspx?sn=13742. Accessed June 13, 2019.

6. Sun Y, Lee HJ, Yang SC, et al. A nationwide survey of mild cognitive impairment and dementia, including very mild dementia, in Taiwan. PLoS One. 2014;9(6):e100303. doi:10.1371/journal.pone.0100303

7. van der Roest HG, Meiland FJ, Maroccini R, Comijs HC, Jonker C, Dröes RM. Subjective needs of people with dementia: a review of the literature. Int Psychogeriatr. 2007;19(3):559-592. doi:10.1017/ S1041610206004716

8. Austrom MG, Carvell CA, Alder CA, Gao S, Boustani M, LaMantia M. Workforce development to provide person-centered care. Aging Ment Health. 2016;20(8):781-792. doi:10.1080/13607863.2015.1119802

9. Khanassov V, Vedel I. Family physician-case manager collaboration and needs of patients with dementia and their caregivers: a systematic mixed studies review. Ann Fam Med. 2016;14(2):166-177. doi:10.1370/afm. 1898

10. Molony SL, Kolanowski A, Van Haitsma K, Rooney KE. Personcentered assessment and care planning. Gerontologist. 2018;58 (suppl_1):S32-S47. doi:10.1093/geront/gnx173

11. Reilly S, Miranda-Castillo C, Malouf R, et al. Case management approaches to home support for people with dementia. Cochrane Database Syst Rev. 2015;5(1):CD008345.

12. Dreier-Wolfgramm A, Michalowsky B, Austrom MG, et al. Dementia care management in primary care : current collaborative care models and the case for interprofessional education. $Z$ Gerontol Geriatr. 2017;50(Suppl 2):68-77. doi:10.1007/s00391-017-1220-8

13. Ganz DA, Koretz BK, Bail JK, et al. Nurse practitioner comanagement for patients in an academic geriatric practice. Am J Manag Care. 2010;16(12):e343-e355.

14. Vickrey BG, Mittman BS, Connor KI, et al. The effect of a disease management intervention on quality and outcomes of dementia care: a randomized, controlled trial. Ann Intern Med. 2006;145(10):713726. doi:10.7326/0003-4819-145-10-200611210-00004

15. Callahan CM, Boustani MA, Unverzagt FW, et al. Effectiveness of collaborative care for older adults with Alzheimer disease in primary care: a randomized controlled trial. JAMA. 2006;295(18):2148-2157. doi:10.1001/jama.295.18.2148

16. Hsu YY, Chen FM, Wang WF, Lin CW, Wu HH. Using classification and regression tree to identify care target combinations for different dementia patients from a medical center in Taiwan. J Med Imag Health In. 2018;8(4):701-705.

17. Sanders AE, Nininger J, Absher J, Bennett A, Shugarman S, Roca R. Quality improvement in neurology: dementia management quality measurement set update. Neurology. 2017;88(20):1951-1957. doi:10.1212/WNL.0000000000003917

18. Black BS, Johnston D, Rabins PV, Morrison A, Lyketsos C, Samus QM. Unmet needs of community-residing persons with dementia and their informal caregivers: findings from the maximizing independence at home study. J Am Geriatr Soc. 2013;61(12):2087-2095. doi:10.1111/jgs.12549
19. Eichler T, Thyrian JR, Hertel J, et al. Unmet needs of communitydwelling primary care patients with dementia in Germany: prevalence and correlates. J Alzheimers Dis. 2016;51(3):847-855. doi:10.3233/ JAD-150935

20. Johnston D, Samus QM, Morrison A, et al. Identification of community-residing individuals with dementia and their unmet needs for care. Int J Geriatr Psychiatry. 2011;26(3):292-298. doi:10.1002/ gps. 2527

21. Han J, Kamber M. Data Mining: Concepts and Techniques. 2nd ed. New York: Morgan Kaufmann Publishers; 2006.

22. Albert MS, DeKosky ST, Dickson D, et al. The diagnosis of mild cognitive impairment due to Alzheimer's disease: recommendations from the National Institute on Aging-Alzheimer's Association workgroups on diagnostic guidelines for Alzheimer's disease. Alzheimers Dement. 2011;7(3):270-279. doi:10.1016/j.jalz.2011.03.008

23. McKhann GM, Knopman DS, Chertkow H, et al. The diagnosis of dementia due to Alzheimer's disease: recommendations from the National Institute on Aging-Alzheimer's Association workgroups on diagnostic guidelines for Alzheimer's disease. Alzheimers Dement. 2011;7(3):263-269. doi:10.1016/j.jalz.2011.03.005

24. Sachdev P, Kalaria R, O’Brien J, et al. Diagnostic criteria for vascular cognitive disorders: a VASCOG statement. Alzheimer Dis Assoc Disord. 2014;28(3):206-218. doi:10.1097/WAD.0000000000000034

25. Emre M, Aarsland D, Brown R, et al. Clinical diagnostic criteria for dementia associated with Parkinson's disease. Mov Disord. 2007;22 (12):1689-1707. doi:10.1002/mds.21507

26. Lee YC, Huang $\mathrm{CH}$, Lin $\mathrm{YC}$, Wu HH. Association rule mining to Identify critical demographic variables influencing the degree of burnout in a regional teaching hospital. Tem J. 2017;6(3):497-502.

27. Yan GJ, Wang WF, Jhang KM, Lin CW, Wu HH. Association between patients with dementia and high caregiving burden for caregivers from a medical center in Taiwan. Psychol Res Behav Manag. 2019;12:55-65. doi:10.2147/PRBM.S187676

28. Larose DT. Discovering Knowledge in Data: An Introduction to Data Mining. Hoboken, NJ: John Wiley and Sons; 2005.

29. Millenaar JK, Bakker C, Koopmans RT, Verhey FR, Kurz A, de Vugt ME. The care needs and experiences with the use of services of people with young-onset dementia and their caregivers: a systematic review. Int J Geriatr Psychiatry. 2016;31(12):1261-1276. doi:10.1002/gps.4502

30. Goldman JG, Vernaleo BA, Camicioli R, et al. Cognitive impairment in Parkinson's disease: a report from a multidisciplinary symposium on unmet needs and future directions to maintain cognitive health. NPJ Parkinsons Dis. 2018;4:19. doi:10.1038/ s41531-018-0055-3

31. Galvin JE, Duda JE, Kaufer DI, Lippa CF, Taylor A, Zarit SH. Lewy body dementia: caregiver burden and unmet needs. Alzheimer Dis Assoc Disord. 2010;24(2):177-181. doi:10.1097/WAD.0b013e3181c72b5d

32. Petersen RC, Lopez O, Armstrong MJ, et al. Practice guideline update summary: mild cognitive impairment: report of the guideline development, dissemination, and implementation subcommittee of the American Academy of Neurology. Neurology. 2018;90(3):126135. doi:10.1212/WNL.0000000000004826

33. Wawrziczny E, Pasquier F, Ducharme F, Kergoat MJ, Antoine P. Do spouse caregivers of young and older persons with dementia have different needs? A comparative study. Psychogeriatrics. 2017;17 (5):282-291. doi:10.1111/psyg.12234 


\section{Publish your work in this journal}

Patient Preference and Adherence is an international, peer-reviewed, open access journal that focusing on the growing importance of patient preference and adherence throughout the therapeutic continuum. Patient satisfaction, acceptability, quality of life, compliance, persistence and their role in developing new therapeutic modalities and compounds to optimize clinical outcomes for existing disease

states are major areas of interest for the journal. This journal has been accepted for indexing on PubMed Central. The manuscript management system is completely online and includes a very quick and fair peer-review system, which is all easy to use. Visit http:// www.dovepress.com/testimonials.php to read real quotes from published authors. 